\title{
Managing the fiscal beast - admin-to-clinician ratio now 3:1
}

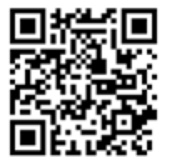

The ranks of senior public healthcare administrators swelled by $12 \%$ over the past 3 years v. a 3.5\% growth among all physicians, pharmacists and pathologists over the same period. This previously unpublicised skewed progression has further bolstered appeals by healthcare professional groups to stop the wide-scale, debilitating freezing of clinical posts.

An Izindaba review of national public healthcare staff data also lends credence to speculation that hard-pressed provincial chief financial managers are panicking after unions (mainly the National Education and Health Workers Union, NEHAWU) won a $10 \%$ wage increase totalling ZAR69 billion over the 2015/16 financial year (part of a 3-year settlement). Bluntly put, the government's ability to afford its own wage increases is looking increasingly shaky, especially going into a bleak 2016/17 financial year. The implications for healthcare delivery - without alternative sources of revenue or the still-distant implementation of actual national health insurance funding - are dire. The widespread freezing of critical clinical service delivery posts in December last year and this January (when most doctors and nurses were seeking them) was, according to the South African Medical Association (SAMA), 'dangerously short-sighted. SAMA Chairperson Dr Mzuksi Grootboom says that not only will it hurt the most vulnerable patient populations and increase existing billion-rand litigation claims, but it will aggravate work pressures as clinical staff are stretched to breaking point after colleagues leave, creating a 'domino effect' and leading to the potential collapse of untenably staffed district hospitals and community health centres. In spite of the overall 3.5\% national increase from 18701 clinical staff in September 2012 to 19352 by September 2015, this clinical staff component plummeted by 327 members $(-1.7 \%)$ from March to September last year exactly when financial austerity measures were introduced. Nursing numbers virtually flatlined from 134153 in September 2012 to 134453 in September 2013 to 134811 in September 2014, before suddenly increasing by $1.2 \%$ to 136439 in September last year.

\section{Budget-breakers remain stubbornly in place}

Says Daygan Eagar, programme manager for the Rural Health Advocacy Project and veteran provincial healthcare financial watchdog, 'While bringing in community service doctors made a huge difference to delivery, and although it increased costs, the glaring primary cost factors have always been higher-than-inflation salary increases and a rapidly growing administrative cadre.' This happened regardless of how the economy was performing, with the current strain on the national fiscus hugely constricting current provincial budget allocations. Both Eagar and Izindaba Treasury sources agreed that government negotiators 'tend to give in' at wage negotiations with the powerful NEHAWU. Grootboom said the subsequent moratoriums on filling posts would result in lost opportunities and chronic staffing shortages this year - with multiple negative knock-on effects.

\section{'The glaring primary cost factors have always been higher-than- inflation salary increases and a rapidly growing administrative cadre.' This happened regardless of how the economy was performing, with the current strain on the national fiscus hugely constricting current provincial budget allocations.}

'Although mention is made of a process whereby critical posts can be unfrozen and advertised, the reality is that this is a long bureaucratic procedure which may require approval from the premier's office. Over the last few years we've seen a mushrooming of middle and senior management positions in the various provincial departments of health at district and provincial level, with a net decrease in service level posts at institution level,' he added. (Izindaba's 12\% expansion figure depicts health directors level up to directors-general). Provinces that have frozen clinical healthcare staff posts are North West, Eastern Cape, KwaZulu-Natal, Mpumalanga and Free State. Eagar said that in his experience, even when 'exceptional circumstances' were proven and budgets could be freed up, it took between 6 months and a year to fill an unfrozen post. 'Where the premier's office is involved, it's virtually impossible to tell whether the appointment is ever finalised,' he added. Every province (with the exception of the Western Cape) was incurring debt, rendering them unable to pay many service providers who responded by refusing to continue delivering often vital services.

Grootboom said that many provincial departments of health received qualified audits by the Auditor General, indicating 'irregular and fruitless expenditure' as the primary cause for failing to achieve a clean audit. Many of their financial woes were caused by dismal supply-chain management. SAMA believes that the freezing of critical posts will be damaging not only to patient care but to working conditions, and that it will increase adverse patient events. Litigation against departments of health has spiralled alarmingly over the last few years (lack of supervision and insufficiently-skilled doctors), with national health minister Dr Aaron Motsoaledi convening a summit to try and mitigate this in April last year and the biggest private sector risk underwriter, the Medical Protection Society, appealing for legal reforms at a similar seminar held in November. Grootboom said the litigation trend was set to continue unless the root causes were effectively dealt with.

\section{Beacon-of-hope hospital flickers and fades}

Eagar cited the deep-rural, well-resourced Zithulele District Hospital, $99 \mathrm{~km}$ from Mthatha, once regarded as a beacon of hope and a model for the country, ${ }^{[1,2]}$ having recently lost a third of its staff. 'This is not because of people wanting to leave, but because the province cannot provide nurse, doctor or comserve posts. They simply haven't replaced anyone. Once you start losing a few staff it has a domino effect. Say you lose three of your eight doctors - the additional burden affects the others and they also leave. Madwaleni District Hospital [a few valleys across from Zithulele] is in crisis and facing collapse,' he added. Eagar also cited several hospitals in North West (among many other provincial hospitals) having cut all elective procedures (hip and knee replacements, for example), increasing disability in the community and creating long-term, costly patient complications. Izindaba sources said provinces were also trying to cut non-core goods and services (such as travel, subsistence or venue hire), but 
the continual wage increases had financial managers eyeing even medicinal supplies and laboratory tests - which Motsoaledi has declared 'non-negotiable'. A Treasury source added: 'Massive amounts go to lower-level non-clinical staff (e.g. cleaners, groundsmen, security guards), who are employed at much higher salary levels than their private sector counterparts - you must remember their packages include medical aid and pensions - you won't get by without paying a ZAR100 000 per annum package.'

Over the past 3 years the total public sector healthcare staff complement (clinical and nonclinical) has dropped from 314859 people to $309367(-1.8 \%)$ - this after continual growth up to 2012, though Izindaba sources stressed that this figure, while illustrating a marked trend, might not be entirely accurate owing to 'data collection issues'.

With an estimated 3\% staff turnover, this means the state should be able to replace 9000 posts without increasing expenditure. Significant savings could be achieved by only filling say 7000 posts, yet unless a pragmatic process for quickly refilling critical posts is in place, the net result could cause nearchaos, given the 400000 annual increase in AIDS patients alone.

\section{Trust-inducing accountability model proposed}

Eagar has a 'bottom-up' management plan, which he has presented to the Parliamentary
Portfolio Committee on Health. It's premised on giving district-level officials the responsibility for cost savings (instead of head office, where there is often little appreciation for the specific situation on the ground) 'They can identify priorities. Province can say you need to save, say, ZAR20 million - not say where or how, but insist on your getting it done.' Otherwise facility managers at district level did not know what to expect or how to plan. What's been missing, Eagar believes, is communication between various levels, 'where a facility doesn't know what District is doing and District doesn't know what Province is doing. He said the Western Cape was 'getting it right', asking district and facility managers to submit in advance posts they'd like to fill. This was fed into a budgeted organogram that enabled everyone to 'know what's possible at the beginning of the year'. Eagar argues that provinces should limit themselves to guidance and support, intervening only where capacity is lacking. Saying that provinces tended to try and centralise control to save on costs, he made a heartfelt appeal for them not to be tempted to cut on low-level public health sector workers, saying that if a cleaner went, it was left to a nurse to clean an operating theatre, again impacting on proper patient care. Most lower-level workers were also not unionised, making them soft targets.

National health department staff figures show that as of September last year there were 511 senior managers (directors up to directors-general) - up from 457 in Septem- ber 2012 (a 12\% increase), with a gradual upward creep every year in between. In the category of 'core administration' (lowlevel admin posts such as financial clerks, credit controllers, material-recording and transport clerks, human resource clerks, managers and cashiers), numbers increased by 4005 people between 2013 and 2015 (also up 12\%). In September 2012 there were 34284 core admin staff, dropping slightly to 33331 in September 2013 and then inexorably growing to 36136 in September 2014 and to 37336 in September last year.

Eagar said that most provinces engaged quite openly with his Rural Health Advocacy group, 'so we know what's going on'. However, with the hugely dysfunctional and troubled Free State, 'it's impossible to tell. They don't co-operate, they close ranks and are pretty antagonistic.'

Izindaba sources said some 'shrewd innovative thinking' would be necessary to create the revenue needed to make universal healthcare coverage fly - and to correct the current skewed human resource healthcare delivery model.

\section{Chris Bateman}

chrisb@hmpg.co.za

S Afr Med J 2016;106(2):131-132.

DOI:10.7196/SAMJ.2016.v106i2.10523

1. Bateman C. Multidisciplinary teams - the rural way forward. S Afr
Med J 2008;98(1):19-22. [http://dx.doi.org/10.7196/SAMJ.860]
2. Bateman C. Leadership, commitment and core values garner
national award. S Afr Med J 2013;103(10):708-709. 